\title{
Metabolomic Profiling of Antioxidant Compounds in Five Vachellia Species
}

\author{
Garland Kgosi More ${ }^{1, * \mathbb{C}}$, Stephen Meddows-Taylor ${ }^{2}\left[\right.$ and Gerhard Prinsloo ${ }^{3}[\mathbb{C}$ \\ 1 College of Agriculture and Environmental Sciences Laboratories, University of South Africa, Florida, \\ Johannesburg 1710, South Africa \\ 2 Department of Life and Consumer Sciences, College of Agriculture and Environmental Sciences, University \\ of South Africa, Florida, Johannesburg 1710, South Africa; mtayls@unisa.ac.za \\ 3 Department of Agriculture and Animal Health, College of Agriculture and Environmental Sciences, \\ University of South Africa, Florida, Johannesburg 1710, South Africa; prinsg@unisa.ac.za \\ * Correspondence: moregk@unisa.ac.za
}

Citation: More, G.K.;

Meddows-Taylor, S.; Prinsloo, G.

Metabolomic Profiling of Antioxidant Compounds in Five Vachellia Species. Molecules 2021, 26, 6214. https:// doi.org/10.3390/molecules26206214

Academic Editor: Fernandez De Simon Brigida

Received: 23 August 2021

Accepted: 8 October 2021

Published: 14 October 2021

Publisher's Note: MDPI stays neutral with regard to jurisdictional claims in published maps and institutional affiliations.

Copyright: (c) 2021 by the authors. Licensee MDPI, Basel, Switzerland. This article is an open access article distributed under the terms and conditions of the Creative Commons Attribution (CC BY) license (https:// creativecommons.org/licenses/by/ $4.0 /)$.

\begin{abstract}
The genus Vachellia, previously known as Acacia, belongs to the family Fabaceae, subfamily Leguminosae, which are flowering plants, commonly known as thorn trees. They are traditionally used medicinally in various countries including South Africa for the treatment of ailments such as fever, sore throat, Tuberculosis, convulsions and as sedatives. The aim of this study was to determine biochemical variations in five Vachellia species and correlate their metabolite profiles to antioxidant activity using a chemometric approach. The antioxidant activity of five Vachellia aqueous-methanolic extracts were analyzed using three methods: 2,2-di-phenyl-1-picrylhydrazyl (DPPH) radical scavenging assay, 2,2'-azino-bis(3-ethylbenzothiazoline-6-sulfonic acid (ABTS ${ }^{+}$) analysis and the ferric reducing antioxidant power (FRAP) assay by means of serial dilution and bioautography with the thin-layer chromatography (TLC) method. Amongst the Vachellia extracts tested, V. karroo, V. kosiensis and V. xanthophloea demonstrated the highest DPPH, $\mathrm{ABTS}^{+}$and FRAP inhibitory activity. The antioxidant activities of $\mathrm{DPPH}$ were higher than those obtained by $\mathrm{ABTS}^{+}$, although these values varied among the Vachellia species. Proton nuclear magnetic resonance $\left({ }^{1} \mathrm{H}\right.$ NMR), coupled with multivariate statistical modeling tools such as principal component analysis (PCA) and orthogonal partial least squares discriminant analysis (OPLS-DA), were performed to profile metabolites responsible for the observed activity. The OPLS-DA categorized the five Vachellia species, separating them into two groups, with V. karroo, V. kosiensis and V. xanthophloea demonstrating significantly higher radical scavenging activity than $V$. tortilis and $V$. sieberiana, which clustered together to form another group with lower radical scavenging activity. Annotation of metabolites was carried out using the ultra-high-performance liquid chromatography-quadrupole time-of-flight mass spectrometry (UHPLC-qTOF-MS), and it tentatively identified 23 metabolites of significance, including epigallocatechin $(m / z=305.0659)$, methyl gallate $(\mathrm{m} / \mathrm{z}=183.0294)$ and quercetin $(m / z=301.0358)$, amongst others. These results elucidated the metabolites that separated the Vachellia species from each other and demonstrated their possible free radical scavenging activities.
\end{abstract}

Keywords: natural products; Vachellia; antioxidant; metabolomics; ${ }^{1} \mathrm{H}$ NMR; UHPLC-qTOF-MS

\section{Introduction}

The etiology of some diseases is due to the inability of a biological system to detoxify oxidative free radicals, leading to the accumulation and imbalances of ROS levels. Diseases such as atherosclerosis, neurodegenerative diseases, rheumatoid arthritis, age-related degeneration and cancer are directly or indirectly initiated by accumulation of ROS [1] Radicals such as peroxide, hydroxyl and peroxyl radicals that are released by cells often result in degradation of proteins and DNA that facilitates these diseases. Oxidative stress and antioxidant defense mechanisms play a key role during various illnesses instigated by microorganisms including bacteria, viruses and neurodegenerative diseases such as 
gonorrhea, diarrhea, human immune deficiency virus (HIV), herpes simplex virus (HSV), cancer, Alzheimer's disease (AD), Parkinson's disease (PD) and amyotrophic lateral sclerosis (ALS) [2]. Despite the currently available treatments for these ailments, the search for new therapeutic drugs should continue considering that synthetic medicines have demonstrated limited success whilst displaying many adverse side effects. Research into the efficacy of medicinal plants and their constituents to treat neurodegenerative diseases is therefore warranted. Technologies such as metabolomics should be utilized to accelerate the process of drug discovery and development from plants used traditionally for the treatment of various ailments.

Vachellia species are widely distributed over Africa and South America, but originate from the region of the Caribbean according to the boreotropical hypothesis of the historical biogeography of Vachellia [3]. They are characterized by their capitate inflorescence and spinescent stipules, which distinguish them from the genus Senegalia [4]. The African species of Vachellia include V. karroo, V. nilotica, V. xanthophloea and V. sieberiana [5]. Medicinal uses of Vachellia species encompass the treatment of diarrhea, fever, sore throat and diabetes, among others (Table 1). Several metabolites produced by Vachellia species, including saponins, tannins, phenols, flavonoids (apigenin, luteolin and quercetin), sugars, anthocyanins, terpenoids, lactones, polyphenols and amino acids, have been reported to contribute positively to in vitro biological activities [6]. Primary and secondary metabolites may be classified as pro-oxidants or oxidants which are significant in stimulating reactive oxygen species (ROS), that play a role in the pathogenesis of various diseases [7]. Natural antioxidants and pro-oxidants in a daily diet and in traditional medicines provide health benefits, and for this reason, extensive research is required to discover natural sources that possess the reducing power of reactive oxygen/nitrogen compounds [8]. Free radical scavenging activity of metabolites from various Vachellia species has previously been reported [9-11], however, there is limited literature on the identification of the compounds involved. One approach to comprehensively determine metabolite profiles and to correlate them to activity is by using metabolomic fingerprinting [12]. Metabolomics allows a quantitative and qualitative analysis of complex mixtures of metabolites in an organism [13]. This technique is preferred since it offers diverse chemical profiles and tools that are relevant in a range of applications, such as toxicology, pharmaceutical drug development [14], genotyping [15] and nutrition and environmental assessment [16]. Coupling of spectrometric analytical methods such as liquid chromatography/mass spectrometry (LC-MS), gas chromatography/mass spectrometry (GC-MS) and nuclear magnetic resonance (NMR) to study metabolomics is a powerful strategy that can be used to obtain a comprehensive analysis of metabolites and assist in compound identification [14]. NMR is mainly preferred as a profiling method to study metabolomics since it is rapid and reproducible [17]. However, a shortcoming of NMR is its low sensitivity compared to mass spectrometry, and hence there is no single best method to study metabolomics and all spectrometric methods are complimentary.

Abdel-Farid et al. [18] profiled the variations of metabolites in different organs of Vachellia species (A. nilotica, A. seyal and A. laeta), and some secondary metabolites were characterized and correlated to the DPPH scavenging activity. However, no studies have investigated or documented the phytochemistry and biological activities of the different Vachellia species that occur in South Africa. The aim of this study was therefore to determine variations of metabolites in these five Vachellia species and to correlate metabolites to the antioxidant activity using a chemometric/metabolomics approach coupled with multivariate statistical modeling tools such as PCA and OPLS-DA. 
Table 1. Medicinal uses of Vachellia species in African countries.

\begin{tabular}{|c|c|c|c|}
\hline Plant Name & Medicinal Uses & Plant Parts Used & $\begin{array}{l}\text { Country of Use/ } \\
\text { References }\end{array}$ \\
\hline \multirow{4}{*}{ V. sieberiana } & $\begin{array}{l}\text { Convulsions, sedative } \\
\text { (mental illness) dizziness }\end{array}$ & Bark & Zimbabwe [19] \\
\hline & Fever & Leaves, Bark, Roots & South Africa [20] \\
\hline & Sore throat & Root & Nigeria [21] \\
\hline & Diarrhea & Bark & South Africa [22] \\
\hline \multirow{5}{*}{ V. xanthophloea } & Diabetes & Bark & Zimbabwe [19] \\
\hline & $\begin{array}{l}\text { Emetic/cathartic, sickle } \\
\text { cell anemia }\end{array}$ & Roots & Tanzania [23] \\
\hline & $\begin{array}{l}\text { Fatigue, indigestion, skin } \\
\text { disorders }\end{array}$ & Bark, Roots & Kenya [24] \\
\hline & $\begin{array}{c}\text { Febrile, fevers, gingivitis, } \\
\text { high cholesterol }\end{array}$ & Leaves, Bark, Roots & South Africa [25] \\
\hline & $\begin{array}{l}\text { Malaria, emetic, mouth } \\
\text { sores, pharyngitis, } \\
\text { tuberculosis symptoms }\end{array}$ & Bark & South Africa [20] \\
\hline \multirow[b]{3}{*}{ V. karroo } & $\begin{array}{c}\text { Diarrhea, dysentery, } \\
\text { gastrointestinal, } \\
\text { venereal diseases }\end{array}$ & Leaves, Roots & South Africa $[25,26]$ \\
\hline & Fractures, diarrhea & Bark & South Africa [27] \\
\hline & $\begin{array}{l}\text { aphrodisiac, sexually } \\
\text { transmitted infections, } \\
\text { urinary schistosomiasis }\end{array}$ & Bark, Roots & Zimbabwe $[27,28]$ \\
\hline V. kosiensis & \multicolumn{3}{|c|}{ No literature on the medicinal uses found } \\
\hline \multirow{4}{*}{ V. tortilis } & Cough & Bark & Nigeria [21] \\
\hline & $\begin{array}{l}\text { Stomach-ache, digestive } \\
\text { indigestion, malaria, }\end{array}$ & Fruits & Yemen [29] \\
\hline & $\begin{array}{l}\text { strengthen bones, kidney } \\
\text { cleanser }\end{array}$ & Roots & Kenya [30] \\
\hline & Diarrhea & Branch tips & South Africa [27] \\
\hline
\end{tabular}

\section{Results}

\subsection{DPPH Radical Scavenging Activities}

The DPPH radical scavenging assay is a well-accepted method to evaluate antioxidant activity. This method is based on the reduction of a purple-colored DPPH radical to a yellow-colored DPPH. The V. Karroo, V. kosiensis and V. xanthophloea extracts exhibited high radical scavenging activity with $\mathrm{IC}_{50}$ values of $4.94 \pm 0.44,5.13 \pm 0.40$ and $4.91 \pm 0.42 \mu \mathrm{g} / \mathrm{mL}$, respectively. Vachellia sieberiana and $V$. tortilis displayed significantly lower DPPH scavenging activity with an $\mathrm{IC}_{50}$ of 87.41 and $70.01 \mu \mathrm{g} / \mathrm{mL}$, respectively.

\subsection{ABTS $^{+}$Radical Scavenging Activity}

Vachellia karroo, V. kosiensis and $V$. xanthophloea exhibited the ability to reduce the $\mathrm{ABTS}^{+}$radical to $50 \%$, with $\mathrm{IC}_{50}$ values of $2.23 \pm 0.51,5.61 \pm 0.63$ and $3.61 \pm 0.45 \mu \mathrm{g} / \mathrm{mL}$, respectively. These results are presented as $\mathrm{IC}_{50}$ values for all tested samples (Table 2). Using both methods, $V$. karroo remained the extract that exhibited the strongest radical scavenging capacity. 
Table 2. Inhibitory concentration ( $\mathrm{IC}_{50}$ ) values of antioxidant activity of five Vachellia species and ascorbic acid (positive control). The $\mathrm{IC}_{50}(\mu \mathrm{g} / \mathrm{mL})$ values are expressed as the mean \pm standard error $(n=3)$. Bold values are considered noteworthy.

\begin{tabular}{cccc}
\hline Plant Extracts & DPPH $\left(\mathrm{IC}_{\mathbf{5 0}} \boldsymbol{\mu \mathrm { g } / \mathrm { mL } )}\right.$ & $\mathrm{ABTS}^{+}\left(\mathrm{IC}_{\mathbf{5 0}} \boldsymbol{\mu \mathrm { g }} / \mathbf{m L}\right)$ & FRAP $\left.^{(\mathrm{IC}} \mathbf{5 0}_{\mathbf{5 0}} \boldsymbol{\mu g} / \mathbf{m L}\right)$ \\
\hline V. karroo & $\mathbf{4 . 9 4} \pm \mathbf{0 . 4 4}$ & $\mathbf{2 . 2 3} \pm \mathbf{0 . 5 1}$ & $28.14 \pm 0.44$ \\
V. kosiensis & $\mathbf{5 . 1 3} \pm \mathbf{0 . 4 0}$ & $\mathbf{5 . 6 1} \pm \mathbf{0 . 6 3}$ & $\mathbf{1 1 . 5 0} \pm \mathbf{0 . 3 4}$ \\
V. sieberiana & $87.41 \pm 0.58$ & $52.03 \pm 0.59$ & $107.09 \pm 0.64$ \\
V. tortilis & $70.01 \pm 0.30$ & $45 \pm 0.58$ & $97.44 \pm 0.54$ \\
V. xanthophloea & $\mathbf{4 . 9 1} \pm \mathbf{0 . 4 2}$ & $\mathbf{3 . 6 1} \pm \mathbf{0 . 4 5}$ & $23.20 \pm 0.34$ \\
Ascorbic acid & $\mathbf{1 . 4 0} \pm \mathbf{0 . 2 1}$ & $\mathbf{1 . 1 0} \pm \mathbf{0 . 2 0}$ & $\mathbf{1 5 . 1 0} \pm \mathbf{0 . 3 9}$ \\
\hline
\end{tabular}

$\overline{\mathrm{DPPH}}=2$,2-diphenyl-1-picrylhydrazyl; $\mathrm{ABTS}^{+}=2,2^{\prime}$-Azino-bis (3-ethylbenzthiazoline-6-sulfonic acid); $\mathrm{IC}_{50}$ value $=$ inhibitory concentration of antioxidants that decrease the radical concentration by $50 \%$.

\subsection{TLC Bioautographic Radical Scavenging Activities}

Evaluation of the radical scavenging activity of Vachellia species by thin-layer chromatography (TLC) bioautography demonstrated clear spots interpreted as inhibition zones on a purple or blue-green background, representing non-active extracts. Out of the three solvent systems investigated to provide superior separation of compounds on a TLC plate, the ethyl-acetate:formic acid:water (ratio: 8:1:1) was the best mobile phase used as it exhibited at least $70 \%$ separation of compounds. Results obtained using the TLC bioautography method were consistent with findings observed in the 96-well serial dilution method. As observed using the TLC bioautography method, V. karroo, V. kosiensis and V. xanthophloea showed high DPPH and $\mathrm{ABTS}^{+}$scavenging activity as compared to Vsieberi$a n a$, and $V$. tortilis (Figure 1), viewed under UV-light under a short wavelength $(254 \mathrm{~nm}$, Figure 1a) and a long wavelength ( $365 \mathrm{~nm}$, Figure 1b). Several fluorescent compounds were observed under a long wavelength in the $V$. sieberiana and $V$. tortilis extracts, although these compounds accounted for less activity. The advantage of using the TLC bioautography method is that it allows analysis of color intensity, which may vary between samples, and may be interpreted as higher to lower activity.
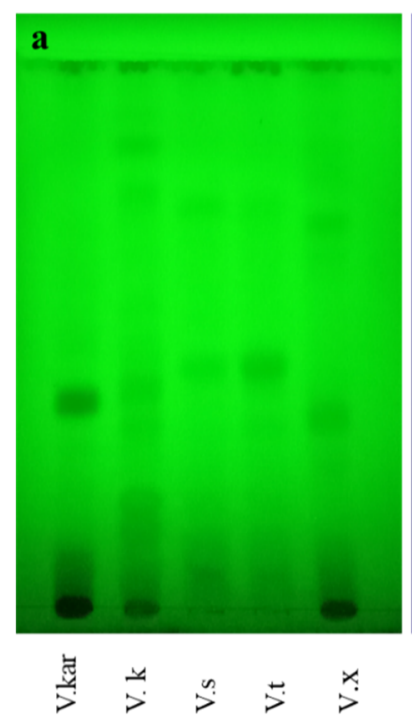
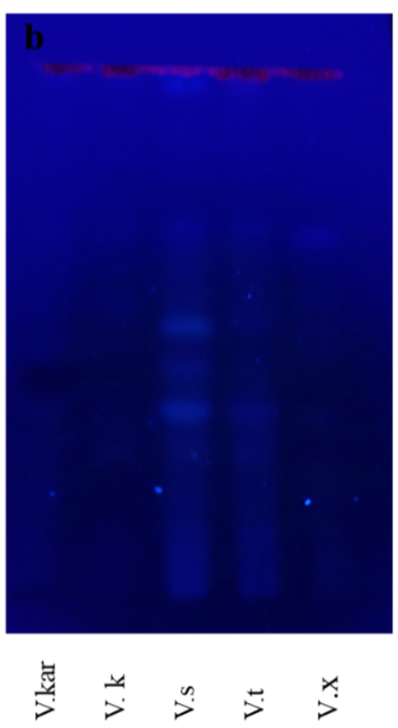
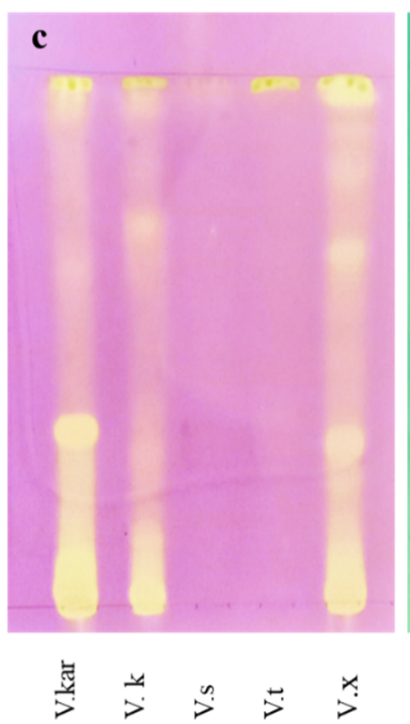

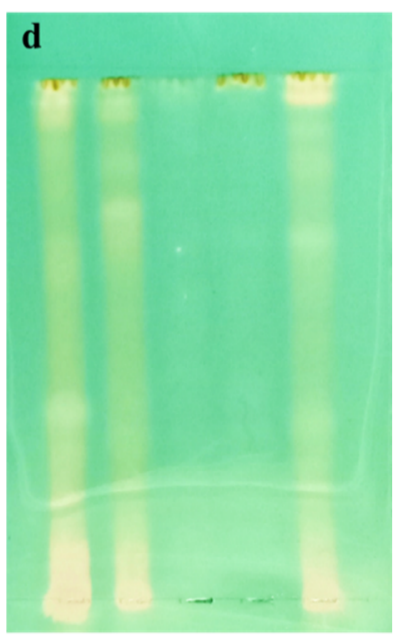

$\stackrel{4}{>} \stackrel{4}{>} \stackrel{x}{>} \stackrel{x}{>}$

Figure 1. TLC chromatogram of five Vachellia extracts showing radical inhibitory compounds visualized using (a) UVlight, short wavelength $(254 \mathrm{~nm})$, (b) UV-light, long wavelength $(365 \mathrm{~nm})$, (c) DPPH and (d) ABTS ${ }^{+}$Chromatogram was developed on a mobile phase: acetic acid:formic acid:water $(8: 1: 1, v / v)$. Clear spots on a purple/blue-green background indicate inhibitory activity (Vx, V. xanthophloea; Vkar, V. karroo; Vk, V. kosiensis) and less active (Vs, V. sieberiana; Vt, V. tortilis). 


\subsection{Ferric Reduction Antioxidant Power (FRAP) Assay}

The reducing power of the extracts changed the yellow ferric tripyridyl triazine $\left(\mathrm{Fe}^{3+}\right.$ TPTZ) to deep blue ferrous $\left(\mathrm{Fe}^{2+}\right)$ depending on the reduction potential of the extracts. Results revealed a trend of inhibitory activity of FRAP which increased as the extract concentrations increased. Similar to the DPPH and $\mathrm{ABTS}^{+}$results, all extracts displayed inhibitory activity of FRAP, with $V$. kosiensis, $V$. xanthophloea and $V$. karroo exhibiting greater reduction antioxidant power with $\mathrm{IC}_{50}$ results recorded as $11.50 \pm 0.34,23.20 \pm 0.34$ and $28.14 \pm 0.44 \mu \mathrm{g} / \mathrm{mL}$, respectively. The antioxidant activities of five Vachellia extracts showed a concentration-dependent response when tested against the $\mathrm{DPPH}, \mathrm{ABTS}^{+}$and FRAP, with a decrease in free radicals at gradual increasing concentrations (Supplementary Figure S3).

\section{5. ${ }^{1}$ H NMR Metabolomic Profiles and Antioxidant Activity Correlation}

${ }^{1} \mathrm{H}$ NMR data were analyzed using SIMCA-P software, and PCA and OPLS-DA plots were constructed to compare the chemical profiles of the plants. PCA is an unsupervised pattern recognition method and was used to ensure an unbiased elucidation of the analyses of the samples. The PC1 and PC2 components together accounted for $95 \%$ of the total variance. As shown in Figure 2a, there were three separate groups between the five (50\% methanolic extracts) Vachellia species. The first cluster represented V. karroo and $V$. xanthophloea, cluster 2 represented $V$. sieberiana and $V$. tortilis, while $V$. kosiensis samples grouped together to form cluster 3 . The OPLS-DA, which is a supervised pattern recognition method, was used to discriminate between samples based on their DPPH scavenging activity. The OPLS-DA (Figure 2b) further separated samples into two clusters, with $V$. karroo, $V$. kosiensis and $V$. xanthophloea defined as cluster 4, and cluster 5 defined by $V$. tortilis and $V$. sieberiana. Cluster 5 consisted of plant samples that showed less DPPH scavenging activity, in contrast to cluster 4, which showed significantly higher DPPH scavenging activity. The OPLS-DA model had a goodness of fit $\left(R^{2} Y\right)$ of 0.993 with predictability $\left(Q^{2} Y\right)$ of 0.989 . A value greater than 0.5 indicates that the model possessed good predictive power [31]. A permutation plot was created to validate the model, and the permutation intercepts were R2 $=(0.0,0.269), \mathrm{Q} 2=(0.0,-0.674)$ (shown in Supplementary Figure S1). Goodness of fit of the OPLS-DA model was further confirmed by cross-validated ANOVA (CV ANOVA), and a significant $p$-value $\left(1.23 \times 10^{-16}\right)$ of the CV ANOVA score, which suggests the robustness of the model (Supplementary Table S1). A receiver operating characteristic curve (ROC) and area under the curve (AUC) performance measurement tool was also developed to assess the probability accuracy of the model, which yielded values of 0.994 and 0.945 . A ROC (AUC) value greater than 0.8 is considered excellent [32]. The ${ }^{1} \mathrm{H}$ NMR spectra of the leaf extracts (Figure 3) were stacked to observe peaks representing metabolites that contribute to the variability of these plants. From the spectra, the samples with high DPPH activity (V. karroo, V. kosiensis and V. xantophloea) exhibited a very similar profile for the aromatic region $\delta 6.0-7.0 \mathrm{ppm}$, whereas the region $\delta 3.5-4.0 \mathrm{ppm}$ is generally dominated by high levels of sugars and aliphatic compounds in the region $\delta 0.5-3.0 \mathrm{ppm}$ for the samples with low DPPH activity (V. sieberiana and V. tortilis). 

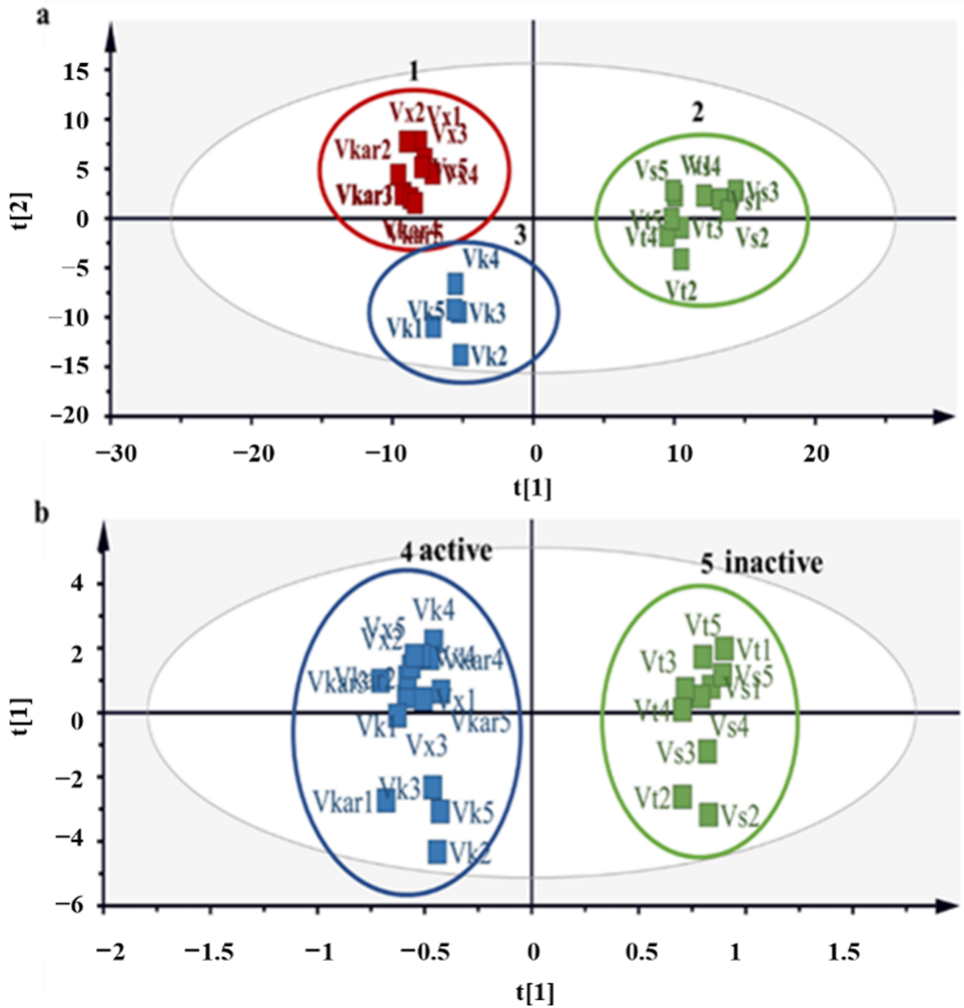

Figure 2. A representation of the PCA score plot (a) and OPLS-DA (b) score plot showing the separation of the plant extracts with high activity in blue (Vx, V. xanthophloea; Vkar, V. karroo; Vk, V. kosiensis) and less active samples in green (Vs, V. sieberiana; $\mathrm{Vt}, \mathrm{V}$. tortilis). Extracts with $\mathrm{IC}_{50} \leq 10$ $\mu \mathrm{g} / \mathrm{mL}$ are considered active and $\mathrm{IC}_{50} \geq 10 \mu \mathrm{g} / \mathrm{mL}$ are deemed inactive.

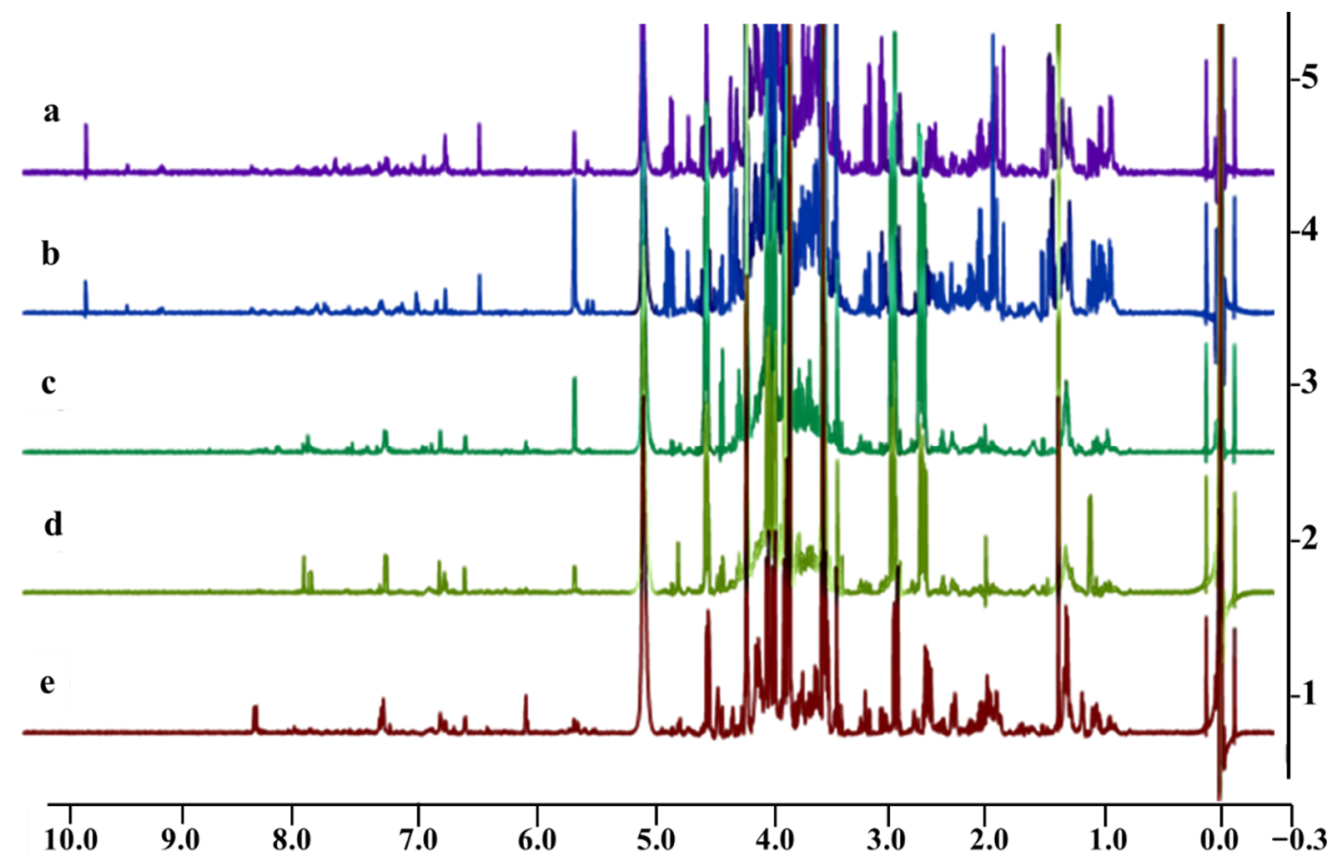

Figure 3. Stacked ${ }^{1} \mathrm{H}$ NMR spectra of leaves' extracts of (a) V. sieberiana, (b) V. tortilis, (c) V. kosiensis, (d) V. xanthophloea and (e) V. karroo.

The ${ }^{1} \mathrm{H}$ NMR spectra of the extracts can be classified into 3 regions based on the chemical shift, which are the aliphatic region (0-3 ppm), the sugar region (3-6 ppm) and 
the aromatic region (6-10 ppm). Figure 3 shows the stacked ${ }^{1} \mathrm{H}$ NMR spectra of five Vachellia extracts with prominent signal peaks of the sugar region in all samples, which are characteristic peaks of glucose, fructose or sucrose. The second most abundant was in the aliphatic region, especially in the less active $V$. sieberiana and $V$. tortilis extracts. This region displays characteristic peaks of carboxylic acid-type compounds such as alanine, leucine, valine, proline and succinic acid. Relatively less peaks were observed in the aromatic region; however, a few clear similar peaks are present in the region of 6.4-7.6, especially in the samples with high activity. Other interesting chemicals shifts of compounds such as trigonelline $(\delta 9.15 \mathrm{ppm})$ and formic acid $(\delta 8.42 \mathrm{ppm})$ were also observed in the less active samples.

${ }^{1} \mathrm{H}$ NMR regions which influence the separation of samples were observed on the S-plot and variable importance of projection (VIP) scores of the OPLS-DA (Figure 4a,b). Scores on the two ends of the S-plot and VIP $\geq 1.0$ with a significance of $p<0.05$ ANOVA were selected as influential scores responsible for the separation of samples [33]. The ${ }^{1} \mathrm{H}$ NMR regions contributing to the separation of samples were shown on the contribution plot (Figure 5) as 2.48, 2.52, 2.72, 2.76, 3.32, 3.6, 4.32, 4.8 and $4.82 \mathrm{ppm}$, and to a lesser extent $5.9,6.0,6.2,6.4,6.6,7.0$ and $7.5 \mathrm{ppm}$, and the negatively associated regions were shown to be $0.92,0.96,1,1.04,1.08,1.28,1.4,1.44,1.84,1.88,1.92,2,2.04,2.08,2.12,2.16,2.2,2.36$, $2.40,2.84,2.88,2.96,3,3.24,3.28,3.36,3.4,3.44,3.48,3.52,3.64,3.68,3.72,3.76,3.84,3.88$, $3.92,4,4.08,4.12,4.48,4.6,4.64$ and $5.44 \mathrm{ppm}$. These regions correlated with buckets on the extreme ends of the S-plot and VIP score values $\geq 1.0$.
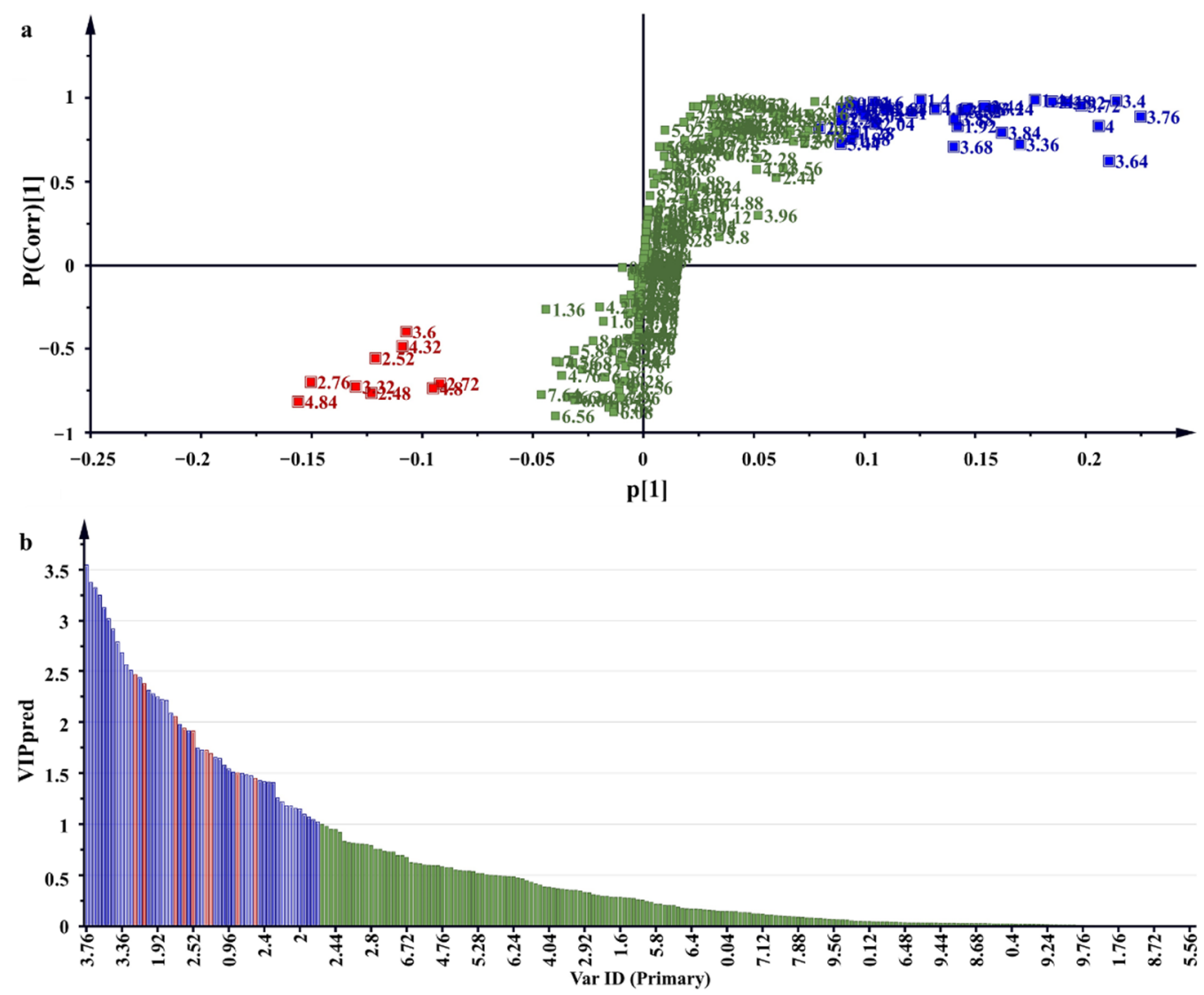

Figure 4. A representative OPLS-DA-derived S-plot (a) and VIP score plot (b) showing ${ }^{1} \mathrm{H}$ NMR regions that contributed to clustering and separation of samples. Cluster (a) ${ }^{1} \mathrm{H}$ NMR regions with high DPPH scavenging activity in red and cluster (b) ${ }^{1} \mathrm{H}$ NMR regions associated with low DPPH scavenging activity in blue. 


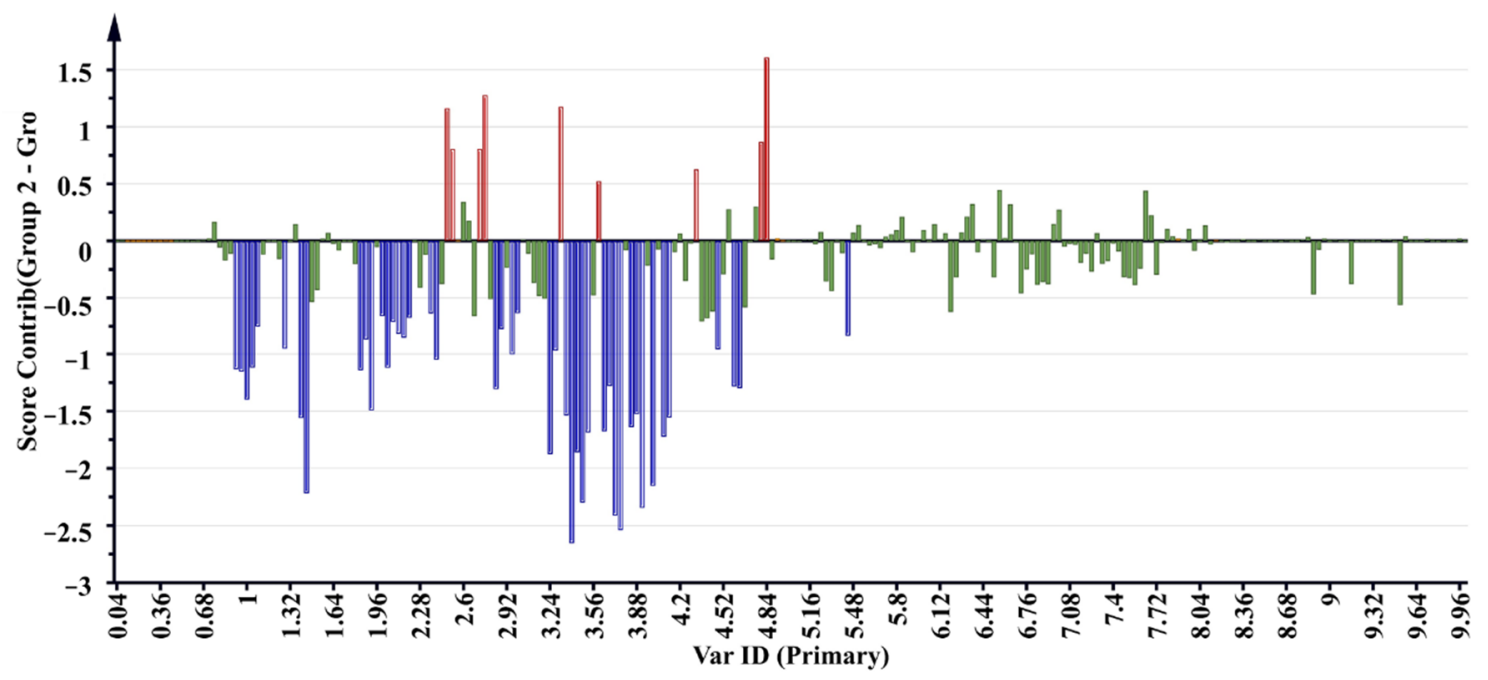

Figure 5. Contribution loading plot of samples representing regions responsible for the clustering of the samples, with bars above the line positively associated and bars below the line negatively associated with the activity.

The ${ }^{1} \mathrm{H}$ NMR buckets obtained from the contribution loading plot (Figure 5) representing compounds of importance that contribute to the clustering of samples were annotated through online network database (HMDB and Chenomx library) searches. Possible annotation and chemical structures of the metabolites were preliminarily evaluated. Metabolite variation between the two sample clusters 4 (active) and 5 (inactive) of the OPLS-DA model (Figure 2) associated with antioxidant activity were assigned and are reported in Table 3.

Table 3. ${ }^{1} \mathrm{H}$ NMR assignment (characteristic ${ }^{1} \mathrm{H}$ NMR peaks) of some compounds contributing to the differentiation of the active and inactive Vachellia extracts obtained using Chenomx software and the HMDB database. $\mathrm{S}$ = singlet; $\mathrm{d}$ = doublet; $\mathrm{m}$, multiplet.

\begin{tabular}{ccc}
\hline Compounds & $\boldsymbol{\delta} \mathbf{1 H}(\mathbf{p p m})$ and Multiplicity & Active/Inactive \\
\hline Isoleucine & $0.92(\mathrm{~d})$ & Inactive \\
leucine & $0.96(\mathrm{~d})$ & Inactive \\
Valine & $1.04(\mathrm{~d})$ & Inactive \\
Alanine & $1.44(\mathrm{~d})$ & Inactive \\
Acetate & $1.92(\mathrm{~s})$ & Inactive \\
Succinate & $2.40(\mathrm{~s})$ & Active \\
Citric acid & $2.52(\mathrm{~d})$ & Active \\
Aspartate & $2.70(\mathrm{~m})$ & Inactive \\
Choline & $3.24(\mathrm{~s})$ & Inactive \\
Betaine & $3.32(\mathrm{~s})$ & Inactive \\
Glucose & $4.84(\mathrm{~m})$ & Inactive \\
Sucrose & $5.44(\mathrm{~d})$ & Inactive \\
Catechin & $5.92(\mathrm{~s})$ & Active \\
Ferulate & $6.44(\mathrm{~s})$ & Active \\
Gallate & $7.10(\mathrm{~s})$ & Active \\
Trigonelline & $9.15(\mathrm{~s})$ & Inactive \\
\hline
\end{tabular}

\subsection{UHPLC-qTOF-MS Analysis Results}

The tentative identification of the metabolite composition of five Vachellia $80 \%$ methanolic extracts was quantitatively performed by ultra-high-performance liquid chromatographyquadrupole time-of-flight mass spectrometry (UHPLC-qTOF-MS) in a negative and positive ionization mode. From the results, as shown in Table 4 and Figure 6, it is evident that a class of polyphenolic compounds characterized by the di- or tri-hydroxyl groups on the B-ring and the meta-5,7-dihydroxyl groups on the A-ring were the prevailing phytoconstituents of this analysis. Catechin (1), epicatechin (2) and epigallocatechin (3) were tentatively iden- 
tified at $m / z=290.07904,290.07904$ and 306.07395, respectively. The latter compounds together with epigallocatechin gallate (EGCG) (5) shown by a peak at $\mathrm{m} / \mathrm{z}=305.0659$ are typical phenolic compounds with potent antioxidant activity abundant in tea, cocoa, berries and wine [34]. Additionally, gallic acid and methyl gallate were annotated at $m / z=169.0133$ and 183.0294, respectively. Phenolic compounds containing a flavonoid moiety were also annotated, and these include luteolin rutinoside $(\mathrm{m} / \mathrm{z}=609.1467)$, kaempferol $(\mathrm{m} / \mathrm{z}=285.0398)$ as well as chrysoeriol rutinoside $(\mathrm{m} / z=607.1663)$. Baicalein (17) and its glucuronide conjugate baicalin (16) flavonoids were shown by the presence of peaks at $\mathrm{m} / \mathrm{z}=269.0443$ and 445.0748 , respectively. Most important was the annotation of epigallocatechin, methyl gallate and quercetin, which are present in all highly active extracts (V. karroo, $V$. kosiensis and $V$. xanthophloea) and may be responsible for the enhanced antioxidant activity observed. Other compounds detected include luteolin glucoside (13), luteolin rutinoside (10) and cyanidin rhamnoside (12), which are renowned as strong inhibitors of DPPH, $\mathrm{ABTS}^{+}$and FRAP radicals $[27,28]$.

Table 4. UHPLC-qTOF-MS metabolites from the methanol-water leaf extracts of five different Vachellia species.

\begin{tabular}{|c|c|c|c|c|c|c|c|c|c|c|c|}
\hline No. & $\begin{array}{c}\text { Tentative } \\
\text { Metabolites }\end{array}$ & $\begin{array}{l}\text { Empirical } \\
\text { Formula }\end{array}$ & $\begin{array}{c}\text { Detected } \\
\text { Mass } \\
(m / z)\end{array}$ & $\begin{array}{c}\text { Mass } \\
\text { Accuracy } \\
\text { (mDa) }\end{array}$ & $\begin{array}{c}\text { MS/MS } \\
\begin{array}{c}\text { Fragmentation } \\
\text { ions }\end{array}\end{array}$ & $\begin{array}{c}\text { Data } \\
\text { Source }\end{array}$ & $\begin{array}{c}\text { Vachellia } \\
\text { karroo }\end{array}$ & $\begin{array}{l}\text { Vachellia } \\
\text { kosien- } \\
\text { sis }\end{array}$ & $\begin{array}{l}\text { Vachellia } \\
\text { tortilis }\end{array}$ & $\begin{array}{l}\text { Vachellia } \\
\text { sieberi- } \\
\quad \text { ana }\end{array}$ & $\begin{array}{c}\text { Vachellia } \\
\text { xan- } \\
\text { thophloea }\end{array}$ \\
\hline 1 & Catechin & $\mathrm{C}_{15} \mathrm{H}_{14} \mathrm{O}_{6}$ & 289.0705 & -0.7 & Trace & NIST 2014 & $\checkmark$ & $x$ & $x$ & $x$ & $x$ \\
\hline 2 & Epicatechin & $\mathrm{C}_{15} \mathrm{H}_{14} \mathrm{O}_{6}$ & 289.0716 & 0.4 & Trace & NIST 2014 & $\checkmark$ & $x$ & $x$ & $x$ & $x$ \\
\hline 3 & Epigallocatechin & $\mathrm{C}_{15} \mathrm{H}_{14} \mathrm{O}_{7}$ & 305.0659 & -0.2 & Trace & NIST 2014 & $\checkmark$ & $\checkmark$ & $x$ & $x$ & $\checkmark$ \\
\hline 4 & Gallic acid & $\mathrm{C}_{7} \mathrm{H}_{6} \mathrm{O}_{5}$ & 169.0133 & -0.4 & 125.02 & NIST 2014 & $x$ & $\checkmark$ & $x$ & $x$ & $\checkmark$ \\
\hline 5 & $\begin{array}{l}\text { Epigallocatechin } \\
\text { gallate }\end{array}$ & $\mathrm{C}_{22} \mathrm{H}_{18} \mathrm{O}_{11}$ & 457.0786 & 1.5 & 169.02 & NIST 2014 & $x$ & $x$ & $x$ & $x$ & $\#$ \\
\hline 6 & Myricetin rutinoside & $\mathrm{C}_{27} \mathrm{H}_{30} \mathrm{O}_{17}$ & 625.1419 & 1.4 & 316.02 & NDP & $\checkmark$ & $\checkmark$ & $\checkmark$ & $x$ & $\checkmark$ \\
\hline 7 & Rutin & $\mathrm{C}_{27} \mathrm{H}_{30} \mathrm{O}_{16}$ & 609.1454 & -0.2 & 300.03 & NIST 2014 & $\checkmark^{*}$ & $\checkmark$ & $x$ & $x$ & $x$ \\
\hline 8 & $\begin{array}{l}\text { Kaempferol } \\
\text { rutinoside } \\
\text { (Nicotiflorin) }\end{array}$ & $\mathrm{C}_{27} \mathrm{H}_{30} \mathrm{O}_{15}$ & 593.1498 & -0.8 & 285.04 & NIST 2014 & $\checkmark$ & $\checkmark$ & $\checkmark$ & $\checkmark$ & $x$ \\
\hline 9 & $\begin{array}{l}\text { Chrysoeriol } \\
\text { rutinoside }\end{array}$ & $\mathrm{C}_{28} \mathrm{H}_{32} \mathrm{O}_{15}$ & 607.1663 & -1.6 & $461.10 ; 299.05$ & NDP & $x$ & $x$ & $\checkmark$ & $\checkmark$ & $x$ \\
\hline 10 & Quercetin rutinoside & $\mathrm{C}_{27} \mathrm{H}_{30} \mathrm{O}_{16}$ & 609.1467 & 1.1 & 300.03 & NIST 2014 & $\checkmark *$ & $\checkmark$ & $\checkmark$ & $\checkmark$ & $\checkmark$ \\
\hline 11 & $\begin{array}{c}\text { Chrysoeriol } \\
\text { glucopyranoside }\end{array}$ & $\mathrm{C}_{22} \mathrm{H}_{22} \mathrm{O}_{11}$ & 461.1072 & -1.2 & 299.02 & NDP & $x$ & $\checkmark$ & $\checkmark$ & $\checkmark$ & $\checkmark$ \\
\hline 12 & Cyanidin rhamnoside & $\mathrm{C}_{21} \mathrm{H}_{20} \mathrm{O}_{10}$ & 431.0989 & 1.1 & 285.03 & Metlin DB & $x$ & $\checkmark$ & $\checkmark$ & $\checkmark$ & $\checkmark$ \\
\hline 13 & Luteolin glucoside & $\mathrm{C}_{21} \mathrm{H}_{20} \mathrm{O}_{11}$ & 449.1096 & 1.2 & 287.05 & NIST 2014 & $x$ & $\checkmark$ & $\checkmark$ & $\checkmark$ & $\checkmark$ \\
\hline 14 & Dihydroacacipetalin & $\mathrm{C}_{11} \mathrm{H}_{19} \mathrm{NO}_{6}$ & 262.1281 & 0.2 & Trace & NDP & $x$ & $\#$ & $\checkmark$ & $\checkmark$ & $\checkmark$ \\
\hline 15 & Kaempferol & $\mathrm{C}_{15} \mathrm{H}_{10} \mathrm{O}_{6}$ & 285.0398 & -0.1 & $151.00 ; 107.01$ & NIST 2014 & $\S$ & $\checkmark$ & $\checkmark$ & $\checkmark$ & $\checkmark$ \\
\hline 16 & Baicalin & $\mathrm{C}_{21} \mathrm{H}_{18} \mathrm{O}_{11}$ & 445.0748 & -2.3 & Trace & NDP & $x$ & $*$ & $x$ & $\#$ & $x$ \\
\hline 17 & Baicalein & $\mathrm{C}_{15} \mathrm{H}_{10} \mathrm{O}_{5}$ & 269.0443 & -0.7 & Trace & NDP & $\checkmark$ & $\#$ & $\checkmark$ & $\checkmark$ & $\#$ \\
\hline 18 & Methyl gallate & $\mathrm{C}_{8} \mathrm{H}_{8} \mathrm{O}_{5}$ & 183.0294 & 0.0 & $183.02 ; 124.03$ & NIST 2014 & $\checkmark$ & $\checkmark$ & $x$ & $x$ & $\checkmark$ \\
\hline 19 & Caffeic acid & $\mathrm{C}_{9} \mathrm{H}_{8} \mathrm{O}_{4}$ & 179.0319 & -2.5 & Trace & NDP & $x$ & $x$ & $x$ & $x$ & $\#$ \\
\hline 20 & $p$-coumaric acid & $\mathrm{C}_{9} \mathrm{H}_{8} \mathrm{O}_{3}$ & 163.0394 & -0.1 & 119.04 & NIST 2014 & $\#$ & $x$ & $\S$ & $\S$ & $x$ \\
\hline 21 & Ferulic acid & $\mathrm{C}_{10} \mathrm{H}_{10} \mathrm{O}_{4}$ & 193.0491 & -1.0 & Trace & NDP & $\S^{*}$ & $\S^{*}$ & $\S^{*}$ & $\S^{*}$ & $x$ \\
\hline 22 & Methyl caffeate & $\mathrm{C}_{10} \mathrm{H}_{10} \mathrm{O}_{4}$ & 193.0501 & -1.9 & Trace & NDP & $\S^{*}$ & $\S^{*}$ & $\S^{*}$ & $\S^{*}$ & $x$ \\
\hline 23 & Quercetin & $\mathrm{C}_{15} \mathrm{H}_{10} \mathrm{O}_{7}$ & 301.0358 & 1.0 & $179.00 ; 151.00$ & NIST 2014 & $\checkmark$ & $\checkmark$ & $x$ & $x$ & $\checkmark$ \\
\hline
\end{tabular}

$\S=$ Observed as a product ion; ${ }^{*}=$ Uncertainty due to similar spectra; $\#=$ Trace level concentrations; $\checkmark=$ present; $\boldsymbol{x}=$ absent. No MS $/$ MS ions for compounds present at trace levels. Bolded are metabolites present in most of the active extracts. 
<smiles>Oc1cc(O)c2c(c1)OC(c1ccc(O)c(O)c1)C(O)C2</smiles><smiles>CC1OC(OCC2OC(Oc3oc4cc(O)cc(O)c4c(=O)c3-c3cc(O)c(O)c(O)c3)C(O)C(O)C2O)C(O)C(O)C1O</smiles><smiles></smiles><smiles>Oc1cc(O)c2c(c1)OC(c1cc(O)c(O)c(O)c1)C(O)C2</smiles>

3<smiles>O=C(O)c1cc(O)c(O)c(O)c1</smiles><smiles>O=C(OC1Cc2c(O)cc(O)cc2OC1c1cc(O)c(O)c(O)c1)c1cc(O)c(O)c(O)c1</smiles><smiles>O=C1CC(c2cccc(O)c2)Oc2cc(OC3OC(CO)[C@@H](O)C(O)C3O)cc(O)c21</smiles><smiles>Cc1ccc(C2CC(=O)c3c(O)cc(OC4OC(CO)C(O)[C@H](O)C4O)cc3O2)cc1O</smiles><smiles>CC1CCCC1O</smiles>

$\mathrm{OH} \mathrm{OH}$<smiles>COc1cc(-c2cc(=O)c3c(O)cc(OC4OC(OC)C(O)C(O)C4O)cc3o2)ccc1O</smiles>

11<smiles></smiles><smiles>CC1OC(Oc2cc3c(O)cc(O)cc3[o+]c2-c2ccc(O)c(O)c2)C(O)C(O)C1O</smiles><smiles>COC1OC(Oc2cc(OO)cc3oc(-c4ccc(O)c(O)c4)cc(=O)c23)C(O)C(O)C1O</smiles><smiles>CC(C)C(OC1OC(CO)[C@H](O)C(O)C1O)C(C)C</smiles>

14<smiles>O=c1c(O)c(-c2ccc(O)cc2)oc2cc(O)cc(O)c12</smiles>

15<smiles>O=C(O)C1OC(Oc2cc3oc(-c4ccccc4)cc(=O)c3c(O)c2O)C(O)C(O)C1O</smiles>

16<smiles>O=c1cc(-c2ccccc2)oc2cc(O)c(O)c(O)c12</smiles>

17<smiles>COC(=O)c1cc(O)c(O)c(O)c1</smiles>

18<smiles>O=C(O)/C=C/c1ccc(O)c(O)c1</smiles>

19<smiles>O=C(O)/C=C/c1ccc(O)cc1</smiles>

20<smiles>COc1cc(/C=C/C(=O)O)ccc1O</smiles>

21<smiles>CCOC(=O)/C=C/c1ccc(O)c(O)c1</smiles>

22<smiles></smiles>

23

Figure 6. Chemical structures of metabolites annotated from Vachellia species.

\section{Discussion}

The DPPH, $\mathrm{ABTS}^{+}$and FRAP results obtained in this study revealed that the Vachellia species tested contain potent antioxidants, although in this case, the scavenging activities of the extracts were lower than ascorbic acid, with the lowest $\mathrm{IC}_{50}$ values being indicative of higher antioxidant capacity in the tested extracts. By comparing the antioxidant methods used in this study, it can be inferred that the quantified antioxidant activity was not equivalent, and the $\mathrm{ABTS}^{+}$method displayed a lower sensitivity compared to the DPPH method. Tshikalange et al. [35] reported that the antioxidant activity of the ethanolic root extracts of $V$. karroo exhibited DPPH scavenging activity with an $\mathrm{EC}_{50}$ of $0.83 \mu \mathrm{g} / \mathrm{mL}$, with the positive control (ascorbic acid) exhibiting an $\mathrm{EC}_{50}$ of $1.44 \mu \mathrm{g} / \mathrm{mL}$. The ability of the $V$. karroo aqueous and acetone extracts to scavenge DPPH and FRAP radicals has been previously reported as $\mathrm{IC}_{50}=0.67,0.62 \mathrm{mg} / \mathrm{mL}$ for DPPH and $0.59,0.56 \mathrm{mg} / \mathrm{mL}$ for FRAP [36]. A comparative study of the antioxidant activity of Vachellia species grown in Saudi Arabia using the DPPH scavenging method showed that $V$. tortilis demonstrated an $\mathrm{EC}_{50}$ of $250.13 \mu \mathrm{g} / \mathrm{mL}$ [37]. An investigation of $V$. nilotica showed high radical scavenging activity $\left(\mathrm{IC}_{50}=6.5 \mu \mathrm{g} / \mathrm{mL}\right)$ 
when the leaves were sequentially extracted with ethanol, although extraction with nonpolar solvents (petroleum ether, benzene and dichloromethane) displayed lower DPPH scavenging activity [38]. A previous study by Katerere et al. [7] reported the TLC bioautographic antioxidant activity of acetone extracts of $V$. galpinii, V. karroo, V. xanthophloea and $V$. sieberiana, where the authors observed three compounds that exhibited strong free radical scavenging capacity. The latter study also demonstrated that chloroform extracts displayed less DPPH scavenging activity as compared to acetone extracts. Similar challenges to those experienced in our study of finding a suitable solvent system for separation of compounds on a TLC plate were also encountered by Katerere et al. [7]. A poor separation of compounds was observed with a moderately polar acidic solvent system: chloroform:ethylacetate:formic acid (CEF: 20:16:4) in all the extracts, and a good separation was obtained with a more polar solvent system: ethylacetate:methanol:water (EMW: 40:5.4:4). DPPH free radical scavenging of $V$. xanthophloea, $V$. tortilis, V. nilotica and $V$. nigrescens displayed an $\mathrm{IC}_{50}$ value ranging from 0.57 to $0.76 \mu \mathrm{g} / \mathrm{mL}$, compared to the positive control (ascorbic acid) with an $\mathrm{IC}_{50}$ of $0.48 \mu \mathrm{g} / \mathrm{mL}$ [34]. The high antioxidant activity observed in our study and previously published studies may be due to the presence of phenolic compounds found in Vachellia species [39,40]. Additionally, compounds in $V$. karoo, V. kosiensis and V. xanthophloea extracts displaying high DPPH and $\mathrm{ABTS}^{+}$scavenging activity suggests that the mechanisms of action of these compounds may be the same for both methods, including either hydrogen atom transfer or single electron transfer, or a combination of both mechanisms.

The main objective of this study was to provide a complete phytochemical profile of five Vachellia species that are responsible for reducing free radicals. This was mainly achieved by exposing extracts to ${ }^{1} \mathrm{H}$ NMR spectroscopy and UHPLC-qTOF-MS analyses, which have been extensively used for profiling of metabolites from plants [18,39]. Due to its high reproducibility, non-destructive and non-invasive nature, NMR was suitable for metabolite fingerprinting. However, even though ${ }^{1} \mathrm{H}$ NMR permits a rapid and accurate quantification of metabolite analysis, detection of metabolites presented in low levels required the use of a more sensitive analytical technique, such as UHPLC-qTOF-MS [17]. The UHPLC-qTOF-MS analysis revealed compounds that were responsible for the separation of Vachellia spp. into potent and less active groups. However, the presence of epigallocatechin, methyl gallate and quercetin, which were only present in the three most active samples (V. karroo, V. kosiensis and V. xanthophloea), was postulated as being responsible for the high activity observed. The presence of these compounds is also supported by the ${ }^{1} \mathrm{H}$ NMR analysis with the characteristic peaks of the catechin compounds observed around 6.0 and $7.0 \mathrm{ppm}$, quercetin at 7.0 and $7.5 \mathrm{ppm}$ and methyl gallate at 3.7 and $7.1 \mathrm{ppm}$ in the ${ }^{1} \mathrm{H}$ NMR spectra. Phytochemical screening of different parts of $V$. nilotica have previously revealed the presence of saponins, tannins, alkaloids, flavonoids and phenols in the ethanol extracts of the leaves, and further investigation utilizing LC-ESI-MS/MS demonstrated the presence of epicatechin-5-gallate, epicatechin, methyl gallate, gallic acid, vitexin, L-arabinose and caffeic acid hexose from the leaf samples of $V$. nilotica [35]. Isolation of phytochemicals from Vachellia species led to the identification of flavonoids (apigenin, luteolin and quercetin) from the leaves of $V$. tortilis, and the presence of apigenin glycoside, quercetin glycoside and isorhamnetin glycoside from leaves, while $n$-hexacosanol, betulin, $\alpha-, \beta$-amyrin and $\beta$ sitosterol from the stem bark has also been previously reported [36]. Our UHPLC-qTOF-MS analysis is in agreement with an earlier study where epicatechin, $\beta$-sitosterol and epigallocatechin were isolated from leaf extracts of $V$. karroo, which demonstrated activity against Listeria monocytogenes [11]. According to the literature, it is evident that the aforementioned metabolites possess antioxidant activities. In vivo studies have demonstrated that epigallocatechin, methyl gallate and quercetin display radical scavenging effects, reduce oxidative stress and exhibit cytoprotective effects on human keratinocytes (HatCaT) and murine (RAW264.7) cell lines [41]. The isolation of compounds from methanol leaf extracts of $V$. sieberiana led to the identification of eight polyphenols, including ellagic acid, gallic acid, isoferulic acid, quercetin, kaempferol, quercetin 3-O- $\beta$-D-glucoside, kaempferol-3- 
alpha-L-arabinoside and 6,7,8-trihydroxy-3,4'-dimethoxydihydroflavone [42]. Xu et al. [43] reported that the antioxidant activities of catechins are closely related to their molecular structures, especially the hydroxyl and galloyl groups.

Despite the lack of published literature on the pharmacological activities of some Vachellia species, especially antioxidant activity, our results demonstrate that $V$. kosiensis and $V$. sieberiana both exhibit antioxidant activity, with our study also elucidating the metabolites that separated the Vachellia species from each other and demonstrating their possible free radical scavenging activities. These results therefore warrant further investigation to assess the antioxidative phytochemicals.

\section{Materials and Methods}

\subsection{Plant Collection}

Five Vachellia species, namely V. sieberiana, V. tortilis, V. karroo, V. kosiensis and V. xanthophloea, were collected into paper bags from the campus of the University of Pretoria and immediately taken to the laboratory to be dried. Five samples of each species were collected from five trees. Plant materials were identified, and voucher specimens were deposited in the $\mathrm{H}$. G. W. J. Schweickerdt Herbarium (PRU), University of Pretoria.

\subsection{Sample Preparation}

\subsubsection{Plant Extraction}

Leaves were dried at room temperature and pulverized to a fine powder using a grinding mill (IKA ${ }^{\circledR}$ MF10, Munich, Germany). Fifty grams (50 g) of powdered plant material were extracted with $500 \mathrm{~mL}$ of $80 \%$ methanol-water. Samples were filtered using the Buchi ${ }^{\circledR}$ filtration system (Sigma-Aldrich ${ }^{\circledR}$, Darmstadt, Germany), and a Stuart ${ }^{\circledR}$ rotary evaporator (IKA ${ }^{\circledR}$, Munich, Germany). was used to concentrate the extracts. Extracted samples were further lyophilized to dryness.

\subsubsection{Sample Preparation for ${ }^{1} \mathrm{H}$ NMR Measurement}

Pulverized plant samples (50 mg) were weighed into a $2 \mathrm{~mL}$ Eppendorf tube and extracted using $1500 \mu \mathrm{L}$ deuterated methanol-water (1:1) with potassium phosphate monobasic $\left(\mathrm{KH}_{2} \mathrm{PO}_{4}\right)$ buffer in deuterium oxide $\left(\mathrm{D}_{2} \mathrm{O}\right)$ and $0.1 \%$ trimethylsilypropionic acid sodium salt (TSP). The buffer was adjusted to $\mathrm{pH} 6.0$ using $1 \mathrm{~N}$ deuterated sodium hydroxide (NaOD). This extraction was performed to target the polar constituents of the plants. Samples were sonicated for $60 \mathrm{~min}(\mathrm{~min})$, centrifuged for $15 \mathrm{~min}$ and the supernatant was filtered through a $0.22 \mu \mathrm{m}$ syringe filter. All samples were transferred to $5 \mathrm{~mm}$ NMR tubes for ${ }^{1} \mathrm{H}$ NMR analyses on a Varian NMR $600 \mathrm{MHz}$ spectrometer (Varian Inc., Palo Alto, CA, USA) with consistent settings, and 32 scans were recorded. Samples were replicated five times.

\subsubsection{Sample Preparation UHPLC-qTOF-MS Measurement}

Extraction of metabolites from the leaves was performed following the method of [33] with slight modifications. Dried powdered leaf samples $(50 \mathrm{mg}$ ) were suspended in $80 \%$ methanol/water, sonicated for $15 \mathrm{~min}$ and centrifuged for $15 \mathrm{~min}$ at $3000 \times g$ at $4{ }^{\circ} \mathrm{C}$. The supernatants were filtered through a $0.22 \mu \mathrm{m}$ nylon syringe filter and evaporated to $1 \mathrm{~mL}$ using an EZ-2 plus evaporator (GeneVac ${ }^{\mathrm{TM}}$, St. Louis, MO, USA). Samples were stored in glass vials for NMR and LC/MS analysis.

\subsubsection{2,2-diphenyl-2-picryl-hydraxyl (DPPH) Free Radical Scavenging Activity Assay}

The DPPH free radical scavenging activity method by Rangkadilok et al. [44] with slight modification was followed. Briefly, $20 \mu \mathrm{L}$ of $10,000 \mu \mathrm{g} / \mathrm{mL}$ of extract was pipetted into $180 \mu \mathrm{L}$ of methanol and added to the top row of a 96-well plate. The solutions were serially diluted onto the remaining wells of the 96-well plate, which contained $100 \mu \mathrm{L}$ of methanol. One hundred microliters of $90 \mu \mathrm{M}$ methanolic DPPH was added to all the wells. The final concentrations of the extract ranged from 3.9 to $500 \mu \mathrm{g} / \mathrm{mL}$. The plates were 
incubated for $30 \mathrm{~min}$ at $25^{\circ} \mathrm{C}$ and the absorbance was measured on a microplate reader (VarioSkan Flash ${ }^{\circledR}$, Thermo Fisher Scientific, Vantaa, Finland) at a wavelength of $517 \mathrm{~nm}$. Ascorbic acid (vitamin C) was used as the positive control at the same concentrations as the extracts. The DPPH inhibitory percent was calculated using formula (1).

$$
\text { DPPH radical scavenging effect }(\%)=\left[\left(\mathrm{A}_{0}-\mathrm{A}_{\mathrm{t}}\right) / \mathrm{A}_{0}\right] \times 100 \%
$$

where $A_{0}$ and $A_{t}$ are the absorbance values of the blank control and tested sample or positive control, respectively. The $\mathrm{EC}_{50}$ value represents the $50 \%$ inhibition ratio of $\mathrm{DPPH}$ activity.

\subsubsection{2,2'-azino-bis(3-ethylbenzothiazoline-6-sulfonic Acid) $\left(\mathrm{ABTS}^{+}\right)$Radical Cation} Scavenging Activity Assay

The $\mathrm{ABTS}^{+}$radical cation scavenging activity assay was assessed using a modified method described by Re et al. [45]. In brief, the $\mathrm{ABTS}^{+}$cation radical was formed by combining $7 \mathrm{mM}$ of ABTS $^{+}$and $2.45 \mathrm{mM}$ of potassium persulfate $\left(\mathrm{K}_{2} \mathrm{~S}_{2} \mathrm{O}_{8}\right)$ in distilled water and kept in the dark for $16 \mathrm{~h}$. Thereafter, the optical density (OD) of the mixture was adjusted with methanol to an absorbance of $0.70( \pm 0.02)$ at $734 \mathrm{~nm}$. The ABTS scavenging activity assay was conducted according to the DPPH scavenging activity assay. The absorbance was measured on a microplate reader (Varioskan-Flash ${ }^{\circledR}$, Thermo Fisher Scientific, Vantaa, Finland) at a wavelength of $734 \mathrm{~nm}$. Ascorbic acid was used as the positive control at the same concentrations as the extracts. The $\mathrm{ABTS}^{+}$scavenging activity percentage was calculated using formula (1) shown in Section 4.2.4.

\subsubsection{Ferric Reducing Antioxidant Power}

The ferric reducing antioxidant power (FRAP) of the extracts was investigated using the FRAP reagent prepared by mixing (10:1:1, v/v/v) acetate buffer (300 mM, pH 3.6), tripyridyl triazine (TPTZ) $(10 \mathrm{mM}$ in $40 \mathrm{mM}$ of $\mathrm{HCl})$ and $\mathrm{FeCl}_{3} \cdot 6 \mathrm{H}_{2} \mathrm{O}(20 \mathrm{mM})$, which was mixed with varying extract concentrations $(3.9-500 \mu \mathrm{g} / \mathrm{mL})$. Ascorbic acid was used as a reference standard and all experiments were performed in triplicate. After $30 \mathrm{~min}$ incubation at room temperature, the absorbance was determined at a wavelength of $593 \mathrm{~nm}$ on a microplate reader (Varioskan-Flash ${ }^{\circledR}$ Flash, Thermo Fisher Scientific, Vantaa, Finland).

\subsubsection{TLC Bioautographic Radical Scavenging Assay}

The thin-layer chromatography (TLC) was developed to carry out separation and assess the DPPH and $\mathrm{ABTS}^{+}$scavenging activity of five Vachellia species in support of the 96-well dilution method. Briefly, extracts were dissolved in methanol and aliquots of $10 \mu \mathrm{L}$ were spotted on three TLC plates (Merck, silica gel $60 \mathrm{~F}_{254}, 10 \times 10 \mathrm{~cm}$ ). The TLC plates were developed in a pre-saturated solvent chamber with various solvent systems of different polarities to determine the best separation of the compounds. These multiple solvent systems included mixtures $(v / v)$ of toluene:ethylacetate:methanol (5:5:1), chloroform:ethylacetate:formic acid (5:5:1) and ethylacetate:formic acid:water (8:1:1) as mobile phase. The mobile phase was allowed to move up on the TLC plate until it reached the $1 \mathrm{~cm}$ solvent front line, then the plates were removed from the chamber to air-dry for $30 \mathrm{~min}$. One plate was visualized under a UV-light (wavelengths of 254 and $365 \mathrm{~nm}$ ) and sprayed with vanillin, after which a heat gun (PROHEAT ${ }^{\circledR}$ Sigma-Aldrich, Master Appliance Corp, Racine, WI, USA) was used to develop the optimal color of the compounds. Other TLC plates were immersed in DPPH and $\mathrm{ABTS}^{+}$solution to observe the radical scavenging activity. The DPPH scavenging activity was indicated by a white-yellow band on a purple background.

\subsection{8. ${ }^{1} \mathrm{H}$ NMR Measurement and Data Analysis}

Spectra of the samples were generated using a $600 \mathrm{MHz}$ NMR operating at a frequency of 599.74. The data were processed using MestReNova software (version 9.0.1, Mestrelab Research, Spain), and phase correction, baseline correction, referencing and normalization 
with respect to the stable standard trimethylsilyl propionate (TSP) were performed on the ${ }^{1} \mathrm{H}$ NMR spectra. The spectral regions from $\delta=0.04$ to $\delta=10.00$ were bucketed into 0.04 ppm bins. The residual water (4.6-5.0 ppm) and methanol (3.28-3.32 ppm) solvent peaks were excluded from the analysis. The processed spectral data obtained were exported to Microsoft Excel and transformed to csv files prior to SIMCA processing. The PCA and OPLS-DA multivariate data analyses were conducted with SIMCA-P software (version 13.0, Umetrics, Umea, Sweden), where pareto scaling was used to further transform data. This scaling method is a more stable technique that amplifies variances between samples. The contribution plot, S-plot and VIP plot were contracted to determine the chemical variation between the samples.

\subsubsection{UHPLC-qTOF-MS Analysis}

The tentative identification of the metabolite composition of five Vachellia $80 \%$ methanolic extracts was quantitatively performed by ultra-high-performance liquid chromatographyquadrupole time-of-flight mass spectrometry (UHPLC-qTOF-MS) in a negative and positive ionization mode. Pulverized leaves $(5 \mathrm{mg}$ ) were extracted with $1.5 \mathrm{~mL}$ of $80 \%$ methanol (LC-grade and ultrapure LC-grade water), homogenized, ultrasonicated for $5 \mathrm{~min}$, and the homogenates were centrifuged for $15 \mathrm{~min}$. The extract of each sample was then filtered using $0.22 \mu \mathrm{m}$ nylon syringe filters and the filtrates were concentrated by evaporation to dryness. The dried extracts were resuspended with $300 \mu \mathrm{L}$ of $50 \%$ methanol and pipetted into $2 \mathrm{~mL}$ HPLC glass vials. Aliquots of extracts were prepared in triplicates and stored at $-20^{\circ} \mathrm{C}$ before analysis. The chromatographic separation and mass spectrometry detection were performed on a Waters Classic UHPLC coupled in tandem to a Waters SYNAPT G1 HDMS mass spectrometer (Waters, Manchester, UK). An HSS T3 C18 column $(150 \times 2.1 \mathrm{~mm}, 1.8 \mu \mathrm{M})$, thermostatted at $60^{\circ} \mathrm{C}$, was used to achieve the separation of metabolites. Elution solvents, Eluent A (10 mM formic acid and acetonitrile) and Eluent B (10 $\mathrm{mM}$ formic acid), were used at a flow rate of $0.4 \mathrm{~mL} / \mathrm{min}$. The initial mobile phase consisted of a gradient combination of Eluents A and B, comprising $98 \%$ of Eluent A, maintained for $1 \mathrm{~min}$. The gradient was altered to $5 \%$ Eluent A by $25 \mathrm{~min}$. These conditions were maintained for $2 \mathrm{~min}$ and thereafter returned to the initial mobile phase conditions. To avoid variations in data, samples were run in triplicate and solvent blanks were included in the run.

The Waters SYNAPT G1 Q-TOF system (Waters, Manchester, UK) was used in Voptics mode to obtain high-resolution mass spectra. Electrospray analysis was performed in positive and negative ionization mode to enable detection of phenolic compounds and other ESI-compatible compounds. Conditions were set as follows: Typical mass accuracies between 1 and $5 \mathrm{mDa}$ were obtained by lock mass calibrant using leucine enkephalin $(50 \mathrm{pg} / \mathrm{mL})$ as a reference. The spectrometer was operated in both ESI positive and negative modes with a capillary voltage of $2.5 \mathrm{kV}$, with the sampling cone at $30 \mathrm{~V}$ and the extraction cone at $4.0 \mathrm{~V}$. The source temperature was $120^{\circ} \mathrm{C}$ and the desolvation temperature was set at $450{ }^{\circ} \mathrm{C}$. Nitrogen gas was used as the nebulization gas at a flow rate of $550 \mathrm{~L} \mathrm{~h}^{-1}$ and cone gas was added at $50 \mathrm{~L} \mathrm{~h}^{-1}$. MassLynx v4.1 (SCN 872) software (Waters Corporation, Milford, MA, USA) was used to control the hyphenated system and to perform all data manipulation. MassFragment v.2.0.w.15 (Waters Corporation, Milford, MA, USA) was used to evaluate all mass spectra in relation to proposed structures. Metabolite profiling was carried out by comparing the mass spectra, retention time (Rt) and ion fragments with data from various databases, including the NIST (National Institute of Standards and Technology) database, DNP (Dictionary of Natural Products: www.dnp.chemnetbase.com, accessed on 22 June 2021), METLIN Mass Spectral Database, MassBank (USA) and mzCloud (Advanced Mass Spectral Database). In addition, data from peer-reviewed literature were used to check for the annotation of the measured masses. 


\subsubsection{Statistical Analysis}

Experiments were conducted in triplicate and all results are presented as mean \pm standard deviation (SD). Experimental data were analyzed using GraphPad Prism software 8.2 (GraphPad Software, CA, USA). For all the analyses, differences were considered statistically significant at $p<0.05$, determined using the Duncan's multiple range test. Significantly discriminant metabolites were characterized by VIP $>1$ and $p \leq 0.05$. A ROC curve was generated using only the metabolites with a significant statistical variation, and the area under the curve (AUC) of the ROC analysis of 0.879 .

\section{Conclusions}

Among the five tested extracts, V. karoo, V. kosiensis and V. xanthophloea extracts clustered together in the OPLS-DA analysis, indicative of a similar chemical profile and additionally showed the highest free radical scavenging effects. The $V$. tortilis and $V$. sieberiana samples grouped together and displayed less activity against DPPH. The ${ }^{1} \mathrm{H}$ NMR- and UHPLC-qTOF-MS-based metabolomics coupled with multivariate statistical tools were used to annotate and identify metabolites contributing to the diversity of the five Vachellia species. By using the various analytical techniques, it is possible to reveal compounds responsible for the DPPH scavenging activity as these compounds are common in all the samples. From these plant extracts, metabolites such as epigallocatechin, methyl gallate and quercetin were putatively identified as major constituents of the three most active plants, all known for their strong free radical scavenging effects. The list of compounds also includes various compounds with antioxidant and medicinal activities and provides an insight into the rich biochemical composition of the Vachellia species and possible interactive effects of the various chemical components in each plant. The findings of the current work provide strong scientific support toward the applications of analytical techniques such as ${ }^{1} \mathrm{H}$ NMR and UHPLC-qTOF-MS to accelerate drug discovery and development. Moreover, ethnobotany coupled with chemometric analytical techniques in the search for therapeutic agents may represent an effective strategy for the identification of leading therapeutic compounds.

Supplementary Materials: The following are available online, Figure S1: Sigmoidal curved graphs of concentration response of five Vachellia extracts against DPPH (a), ABTS (b) and FRAP (c). Figure S2: The OPLS-DA-derived validation plot (permutation times $n=100$ ) of Vachellia samples showing model intercepts of Intercepts $\mathrm{R} 2=(0.0,0.269)$ and $\mathrm{Q} 2=(0.0,-0.674)$. Figure S3: A receiver operating characteristic curve (ROC) area under the curve (AUC) plot with predictably accuracy values of 0.994 and 0.945 . Table S1: Cross-validated ANOVA (CV ANOVA) with a $p$-value $\left(1.23 \times 10^{-16}\right)$ of CV ANOVA. Figure S4: Proton nuclear magnetic resonance ( $\left.{ }^{1} \mathrm{H} N M R\right)$ spectrum of 80\% aqueous-methanol plant extract of Vachellia karroo (a), Vachellia kosiensis (b), Vachellia sieberiana (c), Vachellia tortilis (d) and Vachellia xanthophloea (e), acquired on a $600 \mathrm{MHz}$ NMR.

Author Contributions: Conceptualization, G.K.M., S.M.-T. and G.P.; methodology and investigation, G.K.M.; formal analysis, G.K.M. and G.P.; data curation, G.P.; writing—original draft preparation, G.K.M.; writing-review and editing, G.K.M., S.M.-T. and G.P.; funding acquisition, S.M.-T. and G.P. All authors have read and agreed to the published version of the manuscript.

Funding: The University of South Africa Institutional Research Fund and the Department of Life and Consumer Sciences Output Incentive Fund.

Institutional Review Board Statement: Not applicable.

Informed Consent Statement: Not applicable.

Data Availability Statement: The raw data supporting the findings presented in this study are available in the Mendeley repository: https:/ / data.mendeley.com/library, accessed on 24 September 2021 (Garland kgosi, 2021), doi:10.17632/ghn8ffzsnc.1.

Acknowledgments: We acknowledge A.E. (Braam) van Wyk (Plant taxonomist) and Jason Simpson (Garden Curator) from the University of Pretoria, Department of Soil and Plant Science, for the collection and identification of the plants. We thank Paul Steenkamp and Tebogo Moswetsa 
from the University of Johannesburg for their assistance in performing the UHPLC-qTOF-MS and interpretation.

Conflicts of Interest: The authors declare no conflict of interest.

Sample Availability: Plant samples excluding compounds are available from the authors.

\section{References}

1. Valko, M.; Leibfritz, D.; Moncol, J.; Cronin, M.T.; Mazur, M.; Telser, J. Free radicals and antioxidants in normal physiological functions and human disease. Int. J. Biochem. Cell Biol. 2007, 39, 44-84. [CrossRef]

2. Collin, F. Chemical basis of reactive oxygen species reactivity and involvement in neurodegenerative diseases. Int. J. Mol. Sci. 2019, 20, 2407. [CrossRef]

3. Clarke, H.D.; Downie, S.R.; Seigler, D.S. Implications of chloroplast DNA restriction site variation for systematics of Acacia (Fabaceae: Mimosoideae). Syst. Bot. 2000, 25, 618-632. [CrossRef]

4. Dyer, C. New names for the African Acacia species in Vachellia and Senegalia. J. For. Sci. 2014, 76, 1. [CrossRef]

5. Kyalangalilwa, B.; Boatwright, J.S.; Daru, B.H.; Maurin, O.; Van der Bank, M. Phylogenetic position and revised classification of Acacias (Fabaceae: Mimosoideae) in Africa, including new combinations in Vachellia and Senegalia. Bot. J. Linn. Soc. 2013, 172, 500-523. [CrossRef]

6. Pietta, P.G. Flavonoids as antioxidants. J. Nat. Prod. 2000, 63, 1035-1042. [CrossRef]

7. Katerere, D.R.; Eloff, J.N. Variation in chemical composition, antibacterial and antioxidant activity of fresh and dried Acacia leaf extracts. S. Afr. J. Bot. 2004, 70, 303-305. [CrossRef]

8. Xu, D.P.; Li, Y.; Meng, X.; Zhou, T.; Zhou, Y.; Zheng, J.; Zhang, J.J.; Li, H.B. Natural antioxidants in foods and medicinal plants: Extraction, assessment and resources. Int. J. Mol. Sci. 2017, 5, 96. [CrossRef]

9. Maroyi, A. Acacia karroo Hayne: Ethnomedicinal uses, phytochemistry and pharmacology of an important medicinal plant in southern Africa. Asian Pac. J. Trop. Med. 2017, 10, 351-360. [CrossRef]

10. Mbongeni, K. Antioxidant Activity of Vachellia Species, Pork Quality and Fatty Acid Composition from Pigs Supplemented with Graded Levels of Vachellia tortilis Leaf Meal. Ph.D. Thesis, University of Kwazulu-Natal, Pietermaritzburg, South Africa, 2017. Available online: https:/ / researchspace.ukzn.ac.za/xmlui/handle/10413/16725 (accessed on 8 July 2021).

11. Nyila, M.A.; Leonard, C.M.; Hussein, A.A.; Lall, N. Activity of South African medicinal plants against Listeria monocytogenes biofilms and isolation of active compounds from Acacia karroo. S. Afr. J. Bot. 2012, 78, 220-227. [CrossRef]

12. Riedl, J.; Schreiber, R.; Otto, M.; Heilmeier, H.; Altenburger, R.; Schmitt-Jansen, M. Metabolic effect level index links multivariate metabolic fingerprints to ecotoxicological effect assessment. Environ. Sci. Technol. 2015, 49, 8096-8104. [CrossRef]

13. Verpoorte, R.; Choi, Y.H.; Mustafa, N.R.; Kim, H.K. Metabolomics: Back to basics. Phytochem. Rev. 2008, 7, 525-537. [CrossRef]

14. Moco, S.I.A.; Bino, R.J.; de Vos, C.H.; Vervoort, J.J.M. Metabolomics technologies and metabolite identification. TrAC Trends Anal. Chem. 2007, 26, 855-866. [CrossRef]

15. Ursem, R.A.; Tikunov, Y.M.; Bovy, A.G.; van Berloo, R.; van Eeuwijk, F.A. A correlation network approach to metabolic data analysis for tomato fruits. Euphytica 2008, 8, 181-193. [CrossRef]

16. Lubbe, A.; Pomahačová, B.; Choi, Y.H.; Verpoorte, R. Analysis of metabolic variation and Galanthamine content in narcissus bulbs by HNMR. Phytochem. Anal. 2010, 66, 1157. [CrossRef]

17. Kim, H.K.; Choi, Y.H.; Verpoorte, R. NMR-based plant metabolomics: Where do we stand, where do we go? Trends Biotechnol. 2011, 29, 267-275. [CrossRef]

18. Abdel-Farid, I.B.; Sheded, M.G.; Mohamed, E. Metabolomic profiling and antioxidant activity of some Acacia species. Saudi J. Biol. Sci. 2014, 21, 400-408. [CrossRef]

19. Stafford, G.I.; Jäger, A.K.; Van Staden, J. Activity of traditional South African sedative and potentially CNS-acting plants in the GABA-benzodiazepine receptor assay. J. Ethnopharmacol. 2005, 100, 210-215. [CrossRef] [PubMed]

20. McGaw, L.J.; Lall, N.; Meyer, J.J.M.; Eloff, J.N. The potential of South African plants against Mycobacterium infections. J. Ethnopharmacol. 2008, 119, 482-500. [CrossRef]

21. Kubmarawa, D.; Ajoku, G.A.; Enwerem, N.M.; Okorie, D.A. Preliminary phytochemical and antimicrobial screening of 50 medicinal plants from Nigeria. Afr. J. Biotechnol. 2007, 6, 1690-1696.

22. Cock, I.E.; Van Vuuren, S.F. A review of the traditional use of southern African medicinal plants for the treatment of fungal skin infections. J. Ethnopharmacol. 2020, 241, 112539. [CrossRef]

23. Johns, T.; Mhoro, E.B.; Sanaya, P.; Kimanani, E.K. Herbal remedies of the Batemi of Ngorongoro District, Tanzania: A quantitative appraisal. Econ. Bot. 1994, 48, 90-95. [CrossRef]

24. Muthee, J.K.; Gakuya, D.W.; Mbaria, J.M.; Kareru, P.G.; Mulei, C.M.; Njonge, F.K. Ethnobotanical study of anthelmintic and other medicinal plants traditionally used in Loitoktok district of Kenya. J. Ethnopharmacol. 2011, 135, 15-21. [CrossRef]

25. Corrigan, B.M.; Van Wyk, B.E.; Geldenhuys, C.J.; Jardine, J.M. Ethnobotanical plant uses in the KwaNibela Peninsula, St Lucia, South Africa. S. Afr. J. Bot. 2011, 77, 346-359. [CrossRef]

26. Mulaudzi, R.B.; Ndhlala, A.R.; Kulkarni, M.G.; Finnie, J.F.; Van Staden, J. Antimicrobial properties and phenolic contents of medicinal plants used by the Venda people for conditions related to venereal diseases. J. Ethnopharmacol. 2011, 135, 330-337. [CrossRef] 
27. van der Merwe, D.; Swan, G.E.; Botha, C.J. Use of ethnoveterinary medicinal plants in cattle by Setswana-speaking people in the Madikwe area of the North West Province of South Africa. J. S. Afr. Vet. Assoc. 2001, 72, 189-196. [CrossRef]

28. Chigora, P.; Masocha, R.; Mutenheri, F. The role of indigenous medicinal knowledge (IMK) in the treatment of ailments in rural Zimbabwe: The case of Mutirikwi communal Lands. J. Sustain. Dev. Afr. 2007, 9, 26-43.

29. Al-fatimi, M.; Wurster, M.; Schr, G.; Lindequist, U. Antioxidant, antimicrobial and cytotoxic activities of selected medicinal plants from Yemen. J. Ethnopharmacol. 2007, 111, 657-666. [CrossRef]

30. Koch, A.; Tamez, P.; Pezzuto, J.; Soejarto, D. Evaluation of plants used for antimalarial treatment by the Maasai of Kenya. J. Ethnopharmacol. 2005, 101, 95-99. [CrossRef]

31. Worley, B.; Powers, R. Multivariate analysis in metabolomics. Curr. Metabolom. 2013, 1, 92-107.

32. Mandrekar, J.N. Receiver operating characteristic curve in diagnostic test assessment. J. Thorac. Oncol. 2010, 5, 1315-1316. [CrossRef]

33. Tugizimana, F.; Steenkamp, P.A.; Piater, L.A.; Dubery, I.A. A conversation on data mining strategies in LC-MS untargeted metabolomics: Pre-processing and pre-treatment steps. Metabolites 2016, 6, 40. [CrossRef] [PubMed]

34. Bernatoniene, J.; Kopustinskiene, D.M. The role of catechins in cellular responses to oxidative stress. Molecules 2018, 23, 965. [CrossRef]

35. Tshikalange, T.E.; Mamba, P.; Adebayo, S.A. Antimicrobial, antioxidant and cytotoxicity studies of medicinal plants used in the treatment of sexually transmitted diseases. Int. J. Pharmacog. Phytochem. Res. 2016, 8, 1891-1895.

36. Idamokoro, E.M.; Masika, P.J.; Muchenje, V. A Report on the In Vitro Antioxidant Properties of Vachellia karroo Leaf Extract: A Plant Widely Grazed by Goats in the Central Eastern Cape of South Africa. Sustainability 2017, 9, 164. [CrossRef]

37. Alam, P.; Alajmi, M.F.; Arbab, A.H.; Parvez, M.K.; Siddiqui, N.A.; Alqasoumi, S.I.; Al-Rehaily, A.J.; Al-Dosari, M.S.; Basudan, O.A. Comparative study of antioxidant activity and validated RP-HPTLC analysis of rutin in the leaves of different Acacia species grown in Saudi Arabia. Saudi Pharm. J. 2017, 25, 715-723. [CrossRef]

38. Kalaivani, T.; Mathew, L. Free radical scavenging activity from leaves of Acacia nilotica (L.) Wild. ex Delile, an Indian medicinal tree. Food Chem. Toxicol. 2010, 48, 298-305. [CrossRef]

39. Gong, J.; Chu, B.; Gong, L.; Fang, Z.; Zhang, X.; Qiu, S.; Wang, J.; Xiang, Y.; Xiao, G.; Yuan, H.; et al. Comparison of phenolic compounds and the antioxidant activities of fifteen Chrysanthemum morifolium Ramat cv. 'Hangbaiju' in China. Antioxidants 2019, 8, 325. [CrossRef]

40. Wafaa, H.B.; Hassan, W.; Abdelaziz, S.; Al Yousef, H.M. Chemical composition and biological activities of the aqueous fraction of Parkinsonea aculeata L. growing in Saudi Arabia. Arab. J. Chem. 2019, 12, 377-387. [CrossRef]

41. Kim, E.; Han, S.Y.; Hwang, K.; Kim, D.; Kim, E.M.; Hossain, M.A.; Kim, J.H.; Cho, J.Y. Antioxidant and cytoprotective effects of (-)-epigallocatechin-3-(3"-o-methyl) gallate. Int. J. Mol. Sci. 2019, 20, 3993. [CrossRef]

42. Abdelhady, M.I.S. A novel polyphenolic compound isolated from Acacia sieberiana. Org. Chem. 2016, 9, 6-8. [CrossRef]

43. Xu, Y.Q.; Gao, Y.; Granato, D. Effects of epigallocatechin gallate, epigallocatechin and epicatechin gallate on the chemical and cell-based antioxidant activity, sensory properties, and cytotoxicity of a catechin-free model beverage. Food Chem. 2021, 339, 128060. [CrossRef] [PubMed]

44. Rangkadilok, N.; Sitthimonchai, S.; Worasuttayangkurn, L. Evaluation of free radical scavenging and antityrosinase activities of standardized longan fruit extract. Food Chem. Toxicol. 2007, 45, 328-336. [CrossRef]

45. Re, R.; Pellegrini, N.; Proteggente, A.; Pannala, A.; Yang, M.; Rice-Evans, C. Antioxidant activity applying an improved ABTS radical cation decolorization assay. Free Radic. Biol. Med. 1999, 26, 1231-1237. [CrossRef] 